\title{
Penerapan Asas Resiprositas (Timbal Balik) Dalam Proses Ekstradisi: Studi Kasus Maria Lumowa
}

\author{
Stevani Komara \\ Magister Kenotariatan, Fakultas Hukum Universitas Surabaya \\ Email: stevanikomara84@gmail.com
}

\begin{abstract}
Extradition is known as the process of sending a person who is a defendant or convict who has fled abroad to avoid punishment or trial proceedings. Extradition can be carried out on the basis that the two countries already have previous extradition treaties or based on the principle of reciprocity. It is not uncommon for a country to refuse to hand over a defendant to the applicant's country for various reasons. For example in the case of Maria Lumowa, a fugitive in the bank burglary case for 17 years who was finally extradited back to Indonesia from Serbia. The two countries have never previously entered into an extradition treaty. However, Serbia has a good intention to extradite Maria based on the historical closeness of the two countries' longstanding bilateral relations, as well as remuneration to Indonesia for granting Serbia's extradition request against the perpetrator of theft of customer data in 2015. It can be seen that extradition is not always about having an agreement in order to work, but also seeing the goodwill of the requested country.
\end{abstract}

Keyword: Extradition, International Law, Principle of Reciprocity

Abstrak. Ekstradisi dikenal sebagai sebuah proses pengiriman seseorang yang merupakan seorang terdakwa maupun terpidana yang melarikan diri ke luar negeri untuk menghindari hukuman atau proses persidangan. Ekstradisi dapat dilakukan atas dasar bahwa kedua negara telah memiliki perjanjian ekstradisi terdahulu ataupun berdasarkan pada asas resiprositas. Tidak jarang suatu negara menolak untuk menyerahkan terdakwa kepada negara pemohon karena berbagai alasan. Contohnya dalam kasus Maria Lumowa, buronan kasus pembobolan Bank selama 17 tahun yang akhirnya diekstradisi kembali ke Indonesia dari negara Serbia. Kedua negara tersebut sebelumnya belum pernah membuat perjanjian ekstradisi. Namun Serbia memiliki iktikad baik untuk mengekstradisi Maria berdasarkan kedekatan histori hubungan bilateral kedua negara yang telah terjalin begitu lama, juga sebagai balas jasa kepada Indonesia atas dikabulkannya permintaan ekstradisi Serbia terhadap pelaku pencurian pada data nasabah tahun 2015 silam. Dapat dilihat bahwa ekstradisi tidak selalu mengenai adanya perjanjian agar dapat berjalan, tetapi juga melihat niat baik dari negara yang diminta.

Kata Kunci: Ekstradisi, Hukum Internasional, Asas Timbal Balik

\section{PENDAHULUAN}

\section{Latar Belakang Umum}

Proses ekstradisi sering menjadi masalah dan mendapatkan komentar atas ketidakpuasan beberapa kelompok masyarakat. Hal ini berawal ketika banyaknya warga negara Indonesia yang disangkakan atau dituduh melakukan suatu kejahatan di Indonesia, baik sebelum, saat, maupun yang telah diproses oleh pengadilan, lalu kemudian melarikan diri dari proses hukum. Larinya orang-orang ini keluar negeri menciptakan narasi bahwa pemerintah Indonesia menjadi tidak berdaya untuk mengembalikan orang- orang tersebut untuk menghadapi proses hukum dan kasus tersebut berangsur-angsur lenyap ditelan waktu.

Sebagai contoh adalah Maria Lumowa, seorang buronan dalam kasus pembobolan bank dimana dia melarikan diri begitu lamanya dari proses hukum, sempat memperoleh kewarganegaraan Belanda, membuat pemerintah Indonesia semakin kesulitan untuk memulangkan Maria, karena Belanda yang enggan untuk menyerahkan warga negaranya karena adanya kewajiban untuk melindungi warga negaranya. Ekstradisi merupakan suatu proses pengembalian seseorang yang 
disangkakan atau dituduh melakukan sebuah kejahatan, yang prosesnya hanya dapat terlaksana setelah Negara dimana individu tersebut berada telah mengadakan perjanjian sebelumnya mengenai ekstradisi, dikarenakan proses ekstradisi adalah berkaitan dengan kedaulatan negara, sehingga tidak dapat sertamerta dilakukan.

Ekstradisi sendiri bertujuan agar individu yang melarikan diri dapat dimintakan pertanggung jawaban atas kejahatan yang telah diperbuat dan sebagai langkah preventif agar seorang individu tidak lagi melarikan diri. Namun seiring perkembangannya, kewajiban bagi negara untuk terlebih dahulu memiliki perjanjian ekstradisi agar dapat melakukan ekstradisi dirasa sebagai suatu proses yang cukup rumit dan berbelit-belit, mengingat proses pembentukan sebuah perjanjian yang melibatkan negara sebagai pihak bukanlah suatu hal yang mudah. Prinsip timbal balik atau yang dikenal juga sebagai asas resiprositas sebenarnya menjadi salah satu alternatif untuk melakukan ekstradisi. Seperti upaya Indonesia yang memulangkan Maria Lumowa dari Serbia, sekalipun tidak ada perjanjian ekstradisi sebelumnya. Penelitian ini akan mengelaborasikan lebih jauh apakah asas resiprositas dapat diimplementasikan secara nyata dalam upaya suatu negara untuk melakukan ekstradisi, khususnya mengenai apakah asas resiprositas benar-benar dikenal dan diakomodir dalam hukum internasional.

\section{METODE}

Soerjono Soekanto (2006), dalam tulisannya menyatakan suatu penelitian adalah suatu kegiatan ilmiah yang didasarkan pada metode, sistematika, dan pemikiran tertentu yang bertujuan untuk mempelajari satu atau beberapa gejala hukum tertentu, dengan jalan menganalisanya. Kecuali ini, maka juga diadakan pemeriksaan mendalam terhadap fakta hukum tersebut untuk kemudian mengusahakan suatu pemecahan atas permasalahan yang timbul di dalam gejala yang bersangkutan.

Tipe penelitian yang digunakan dalam penelitian ini adalah tipe penelitian hukum yuridis normatif, yaitu penelitian hukum yang mengacu pada hukum internasional dan peraturan perundang-undangan tertentu yang berkaitan dengan permasalahan yang dibahas, untuk selanjutnya dianalisis hubungan antara aturan-aturan hukum tersebut agar dapat menghasilkan penjelasan yang sistematis

Adapun pendekatan yang digunakan dalam penelitian ini adalaha Statute Approach dan Conceptual Approach. Pendekatan perundang-undangan (Statute Approach) dilakukan dengan menelaah semua peraturan perundang-undangan dan regulasi yang bersangkut paut dengan isu hukum yang sedang dibahas (Peter Mahmud Marzuki, 2008), dan pendekatan konseptual (Conceptual Approach) beranjak dari pandangan-pandangan dan doktrin-doktrin yang berkembang dalam ilmu hukum (Peter Mahmud Marzuki, 2008). Pendekatan ini didasarkan pada pendapat para ahli hukum yang diperoleh dari buku-buku, literatur, jurnal, artikel, dan karya ilmiah yang berkaitan ketentuan ekstradisi dalam hukum internasional.

\section{HASIL DAN PEMBAHASAN}

Ekstradisi dipahami sebagai suatu praktik pengambilan dan membawa seseorang pelaku kejahatan atau penyerahan dari satu negara ke negara lain, atas permintaan, orang yang dituduh atau dihukum karena melakukan kejahatan serius di wilayah hukum negara yang meminta ekstradisi (Joanna Harrington, 2018).

Indonesia telah mengatur mengenai ekstradisi, yang dituangkan dalam UndangUndang No. 1 tahun 1979, dimana dalam Pasal 1 dituliskan bahwa ekstradisi adalah penyerahan seseorang yang disangka atau dipidana karena melakukan suatu kejahatan di luar wilayah negara yang menyerahkan dan di dalam yurisdiksi wilayah negara yang meminta penyerahan tersebut, karena berwenang untuk mengadili dan memidananya.

Ekstradisi sendiri hadir di tengahtengah masyarakat internasional sebagai suatu upaya untuk mengusahakan pencegahan, pemberantasan dan bahkan memberikan hukum bagi pelaku kejahatan internasional 
ataupun pelaku kejahatan dalam lingkup lintas negara (Yordan Gunawan, R. Wilanti, 2015)

Ekstradisi pada dasarnya akan dapat terlaksana apabila di antara kedua negara yang mengajukan permintaan dan negara dimana pelaku berada, telah mengadakan sebuah perjanjian internasional mengenai ekstradisi.

Cara lain yang dapat dilakukan dalam hal tidak atau belum adanya perjanjian ekstradisi antar kedua negara, maka ekstradisi dapat dilakukan atas dasar hubungan baik dan jika kepentingan negara menghendakinya (Pasal 2 ayat 1 dan 2 UU No. 1 Tahun 1974)

Proses ekstradisi dimulai dengan permintaan ekstradisi yang diajukan melalui saluran diplomatik, baik itu Menteri ataupun kepala negara, baik secara langsung atau tidak langsung, melalui duta besar dari negara yang bersangkutan.

Permintaan untuk melakukan ekstradisi harus dilakukan oleh negara yang memang memiliki yurisdiksi untuk mengadili dan menghukum pelaku kepada negara dimana pelaku sedang berada atau melarikan diri. Dalam hal ini, negara dimana pelaku berada tidak boleh menyerahkan langsung orang tersebut kepada negara yang memiliki yurisdiksi, karena hal tersebut akan berujung kepada pelanggaran Hak Asasi Manusia berkait dengan hak atas rasa aman dan kebebasan dari rasa takut selama berada di negara tersebut (Belardo Prasetya, 2020)

Adapun beberapa pendapat lain mengenai ekstradisi dapat dilihat dalam beberapa sumber maupun pendapat, sebagai contoh dalam peraturan international maupun ahli sebagai berikut:

1. J.G. Starke, mendefinisikan ekstradisi yaitu "the process whereby under treaty or upon a basis of reciprocity one state surrenders to another state at its request a person accused or convicted against the laws of the requesting state competent to try the alleged offender (J.G. Starke, 1972)

2. I Wayan Parthiana pada suatu kesempatan menyatakan bahwa ekstradisi adalah penyerahan secara formal yang dilakukan baik berdasarkan perjanjian ekstradisi yang diadakan sebelumnya atau berdasarkan prinsip timba balik, atas seseorang yang dituduh melakukan tindak pidana kejahatan (tersangka, tertuduh, terdakwa) atau atas seseorang yang telah dijatuhi hukuman atas kejahatan yang dilakukannya (terhukum, terpidana) oleh negara tempatnuya melarikan diri atau berada atau bersembunyi kepada negara yang memiliki yurisdiksi untuk mengadili atau menghukumnya, atas permintaan dari negara tersebut dengan tujuan untuk mengadili atau melaksanakan hukumannya. (I Wayan Parthiana, 1990)

Beberapa definisi tersebut menunjukkan unsur-unsur yang dibutuhkan agar dapat dilakukannya ekstradisi, yaitu perlu adanya negara yang diminta dan juga negara peminta. Negara peminta adalah negara yang memiliki yurisdiksi untuk mengadili pelaku baik karena pelaku adalah merupakan warga negara dari negara peminta ataupun si pelaku melakukan kejahatannya di negara tersebut atau yang sering dikenal dengan istilah Locus Delicti. Selain subjek, yaitu negara, tentu saja perlu adanya objek untuk ekstradisi dapat terjadi, dalam hal ini yaitu pelaku kejahatan. Meskipun pelaku kejahatan dalam hal ini dikategorikan sebagai objek, perlu digarisbawahi bahwa objek yang dimaksud adalah sebagai objek perjanjian dengan tetap mengedepankan hak dan kewajiban pelaku sebagai individu yang perlu dilindungi kodratnya sebagai manusia. (Deli Waryenti, 2012). Dilanjutkan dengan proses ekstradisi, sebagai sempat disinggung di atas bahwa ekstradisi dilakukan dengan adanya permintaan terlebih dahulu oleh negara peminta kepada negara yang diminta yang didahului oleh perjanjian ekstradisi, namun dalam hal negara tidak memiliki perjanjian, dapat diberlakukan asas timbal balik untuk memuluskan proses ekstradisi tersebut, dan pada akhirnya negara yang diminta perlu memastikan proses penyerahan sesuai dengan ketentuan peraturan perundang-perundangan di negara tersebut.

Dalam kasus Maria Lumowa, buron kasus LC fiktif, dalam pelariannya selama 17 tahun akhirnya menemukan titik terang. Setelah ditolak oleh Belanda untuk memulangkan Maria ke Indonesia, pelarian 
Maria berakhir di Serbia pada tahun 2019, yang sejatinya Serbia tidak memiliki perjanjian ekstradisi dengan Indonesia, namun proses ekstradisi Maria ke Indonesia dapat berhasil melalui pendekatan yang dilakukan oleh Duta Besar Republik Indonesia untuk Republik Serbia dan Montenegro, yang merupakan balas jasa Serbia atas dikabulkannya permintaan oleh Serbia atas pemulangan pelaku pencurian data nasabah pada tahun 2015. (iNews.id, 2020).

Terlihat bahwa asas resiprositas dalam proses ekstradisi ini memiliki jangkauan hukum yang sangat luas dan hampir tidak terbatas, yang menjadi penting dan relevan adalah adanya komitmen dari seluruh negara di dunia untuk memberantas kejahatan sekecil apapun, dan penerapan asas resiprositas ini pun terhadap yurisdiksi negara lain tidak akan menyebabkan ataupun mengabaikan kedaulatan dari negara lain.

Asas resiprositas tidak hanya sekedar menjadi sebuah asas yang berlaku pada masyarakat internasional. Hal ini sejatinya sudah diatur dalam Undang-Undang Nomor 1 Tahun 1979 tentang Ekstradisi, dalam Pasal 2 Ayat 2 bahwa dalam hal belum ada perjanjian internasional mengenai ekstradisi antara kedua negara, maka ekstradisi tetap dapat dilaksanakan atas dasar hubungan baik dan demi kepentingan negara. Namun dengan kemudahan yang ditawarkan oleh asas ini, tetap masih ada koridor-koridor hukum yang tetap perlu untuk dipatuhi, semisal untuk tidak mengekstradisi warga negara sendiri maupun pelaku kejahatan politik.

Namun, pertanyaan berikut yang muncul adalah apakah asas resiprositas merupakan bagian dari sumber hukum internasional sebagaimana diatur dalam Statuta Mahkamah Internasional. Dalam Statuta Mahkamah Internasional Pasal 38 ayat 1, mengatur tentang sumber-sumber hukum internasional, yaitu perjanjian internasional, kebiasaan internasional, asas hukum yang diakui oleh negara beradab, putusan pengadilan, dan ajaran para ahli.

Merujuk pada isi pasal tersebut, berarti bahwa asas-asas hukum merupakan suatu sumber hukum yang sah, bahkan asas ini pun tidak hanya mendasari hukum internasional saja melainkan juga tetapi juga hukum nasional. Sebagaimana diutarakan oleh Mochtar Kusumaatmadja (2002), sama seperti halnya asas resiprositas, asas ini menjadi sebuah asas universal yang dianut oleh berbagai negara. Asas lain yang dapat dijadikan contoh adalah Pacta Sunt Servanda. Asas ini menjadi asas umum dalam hukum perdata yang menyatakan bahwa suatu perjanjian yang sudah dibuat harus ditepati. Asas-asas hukum umum yang dikenal tersebut termasuk sebagai sumber hukum primer, selain kodratnya yang berdiri di samping perjanjian dan kebiasaan internasional. Asas-asas dimaksud juga memberikan kontribusi penting terhadap perkembangan hukum internasional dalam hubungannya dengan perkembangan sistem hukum positif (Mochtar Kusumaatmadja, 2002).

\section{KESIMPULAN}

Bahwa dalam praktiknya, asas resiprositas merupakan asas hukum umum yang keberadaannya diakui oleh Hukum Internasional dan diatur dalam Statuta Mahkamah Internasional. Asas ini dapat menjadi jawaban bagi negara-negara yang belum atau tidak mempunyai perjanjian ekstradisi, tetapi membutuhkan tindakan ekstradisi. Asas resiprositas menjadi sebuah solusi untuk meniadakan kompleksitas bagi negara-negara dalam melaksanakan proses ekstradisi demi menjaga ketertiban hukum.

\section{UCAPAN TERIMA KASIH}

Apresiasi dan terima kasih yang tidak terhingga disampaikan terhadap para editor dan reviewer dari Jurnal Ilmu Sosial dan Pendidikan (JISIP) yang telah membantu mendukung dan meningkatkan eksistensi maupun kualitas penelitian ini. Terima kasih juga kepada orang tua dan segenap keluarga yang telah memberikan dukungan moril selama dilaksanakannya penelitian ini.

\section{DAFTAR PUSTAKA}

Gunawan, Yordan, Wilanti. R. 2015. The Urgency of Rome Statute of the 
International Criminal Court Reflection. US-China Law Review.

Harrington, Joanna. 2018. The Role of Human Rights Obligations in Canadian Extradition Law. Canada: Canadian Yearbook of International Law.

Kusumaatmadja, Mochtar. 2002. Pengantar Hukum Internasional. Bandung: Aktual.

Mar'uf, Irfan (ed.). 2020. Cerita Mengagetkan Yasonna tentang Maria Lumowa, Presiden Serbia Sampai Ikut Bicara. iNews.id

Marzuki, Peter Mahmud. 2008. Penelitian Hukum. Jakarta: Kencana Prenada Media Group.

Parthiana, I Wayan. 1990. Ekstradisi dalam Hukum Internasional dan Hukum Nasional Indonesia. Bandung: CV Mandar Maju.

Prasetya, Belardo. 2020. Transnational Criminal Case Settlement Through International Cooperation (A Case Study of Harun Masiku). Serang: Ajudikasi: Jurnal Ilmu Hukum.

Soekanto, Soerjono. 2006. Pengantar Penelitian Hukum. Depok: UI-Press.

Starke, J.G. 1972. An Introduction to International Law: $7^{\text {th }}$ edition. London: Butterworths.

Waryenti, Deli. 2012. Ekstradisi dan Beberapa Permasalahannya. Lampung: Fiat Justitia Jurnal Ilmu Hukum. 